\title{
The Effects of Different Seaweed Doses on Yield and Nutritional Values of Hydroponic Wheatgrass Juice
}

\section{Muhammet Karaşahin*}

Department of Biosystem Engineering, Faculty of Engineering and Natural Sciences, Necmettin Erbakan University, 42310 Ereğli/Konya, Turkey

\begin{tabular}{l}
\hline A R T I C L E I N F O \\
Research Article \\
Received 30 September 2016 \\
Accepted 27 January 2017 \\
\hline
\end{tabular}

Keywords:

Hydroponic

Nutritional value

Seaweed

Wheatgrass juice

Yield

${ }^{*}$ Corresponding Author:

E-mail: mkarasahin@konya.edu.tr \begin{abstract}
A B S T R A C T
This research was conducted to determine the effects of different seaweed doses on yield and nutritional values of hydroponic wheatgrass (Triticum aestivum L.) juice in the climatization chamber of Karabuk University, Eskipazar Vocational School, Department of Crop and Animal Production between the dates of 15.01.2015 and 15.06.2015. In the research, four different seaweed doses (Control; 0, D1; 150, D2; 300, D3; 450 and D4; $600 \mathrm{ppm}$ ) and control were applied to irrigation water and their effects on the content of biomass rate, biomass and grass yield, grass juice yield and $\mathrm{pH}$, plant height and root length, biomass and grass dry matter rate, grass juice energy and macronutrient values (protein, carbohydrate, fat, dietary fiber and ash) were analysed. According to the results, while the highest biomass and grass yield, plant height values were obtained from D1, D2, D3 and D4 treatments, the highest grass juice yield and root length were obtained from D3 treatment. The highest pH, grass dry matter content was obtained from control treatment. Seaweed dose treatments were not had influence on grass juice energy values. However, the rise in the grass juice yield was caused a rise in the total energy values in the unit area. D3 treatments can be recommendable to achieve the highest grass juice yield.
\end{abstract}

\section{Introduction}

Fertilizers are the most important input in agricultural production. A growing reaction against the rising negative direct or indirect effects of chemical fertilizers, especially nitrogene on human health and environment has come up. As a result, farmers start to prefer organic production methods or low-input sustainable agriculture as an alternative to chemical-sourced production method. Current organic fertilizers cannot meet these increasing demands. The use of seaweed extracts as organic fertilizers to meet this need is a viable option. Seaweeds are consumed as food source for humans and animals and also as polysaccharides source like agar, alginic acid and carrageenan. They are valuable organic fertilizer sources because they include growth-promoting hormones such as indole acetic acid, indole butyric acid, cytokinin, auxin and abscisic acid, trace elements (Fe, $\mathrm{Cu}, \mathrm{Zn}, \mathrm{Co}, \mathrm{Mo}$, Mn, Ni), vitamins and amino acids (Sharma et al., 2012; Latique et al., 2013; Peinado et al., 2014; Shahbazi et al., 2015). Many researches have claimed that seaweeds have resistance to bad environment conditions and have effects of enlarging of plant and nutrient uptake and increasing fertility (Arthur et al., 2013; Zamani et al., 2013; Rajarajan et al., 2014; Sabir et al., 2014).

Interest in hydroponic farming continues to increase day by day. When compared to soil based production system, hydroponic farming requires much less water, has high stability power efficiency, reduce environmental pollution caused by fertilizers and pest and disease control is easy with hydroponic farming. Hydroponic production system is made up providing moisture, heat, light and etc. required for germination and growth of the grains in a soilless environment. After grains germinate, roots mesh into each other and get the carpet appearance, and the green parts reach $20-25 \mathrm{~cm}$ height within 6-8 days. In hydroponic production yield and quality are affected by some factors such as system management, seed type and quality used, water quality, $\mathrm{pH}$, timing and frequency of irrigation, pre-soaking time, plant nutrients presence, temperature, carbon dioxide and humidity, light intensity and position seeding density and growth period (Fazaeli et al., 2012).

The researches on wheatgrass juice nutritional value have stated that in high concentrations, it contains pharmacological enzymes such as chlorophyll and protease amylase, lipase, cytochrome oxidase, transhidrogenaz, superoxide dismutase and bioflavonoids such as apigenin, quercetin, luteolin; it is rich in terms of vitamin $\mathrm{A}, \mathrm{B}, \mathrm{C}, \mathrm{E}$ and $\mathrm{K}$ and contains calcium, phosphorus, potassium, iron, magnesium, sodium, sulphur, zinc, boron, manganese, molybdenum, selenium and 17 different amino acids (Shah et al., 2011; Anonymous, 2012). It is also stated that Wheatgrass juice 
is used in the treatments of respiratory diseases such as asthma, bronchitis, skin and kidney diseases, leukemia, mediterranean anemia, breast cancer and has some properties such as anti-inflammatory, detoxification, antioxidant, anticarcinogenic, the immune system intensifier, laxative, diuretic, astringent, antibacterial, antidiabetic atherosclerosis inhibitory, reproductive function healer and anti-aging (Ashok, 2011; Aydos et al., 2011; Degraff Loraine, 2011; Rana et al., 2011; Singh et al., 2012; Patel Janki and Patel Piyush, 2013).

This research is justified by the lack of researches on grass juice yield and nutritional value despite the abundance od researches on the effects of wheatgrass juice on health. This study has been conducted to determine the effects of different seaweed doses on yield and nutritional values of hydroponic wheatgrass (Triticum aestivum L.) juice.

\section{Materials and Methods}

This research was conducted in the climatization chamber of Karabuk University, Eskipazar Vocational School, Department of Crop and Animal Production between the dates of 15.01.2015 and 15.06.2015. Plastic cuvettes $30 \times 50 \times 7 \mathrm{~cm}$ in size were used as germination container. City network was used as water supply in the irrigation system (Table 1).

In the study, Bejostaja 1 (Triticum aestivum L.) variety of wheat and SeaMax a source of organic fertilizer completely water-soluble micro-granule seaweed (Ascophyllum nodosum) extract was used as materials (Table 2). Wheat grains were steeped in $1 \%$ sodium hypochlorite solution for 30 minutes in all applications.

Trials were planned as three replications in accordance with completely randomized designs. The study was conducted by applying $4.0 \mathrm{~kg} / \mathrm{m}^{2}$ seed density, 7 days growing period (harvest time), $24^{\circ} \mathrm{C}$ ambient temperature, ebb and flow irrigation method, $20 \mathrm{sec} / 120 \mathrm{~min}$ irrigation time and frequency, 5000 lux - $19 \mathrm{~h}$ - yellow, respectively light intensity, time and colour in hydroponic climatization chamber (Figure 1). Wheatgrass juicer was used in obtaining grass juice (Figure 2). In the research, four different seaweed doses and control (Control; 0, D1; 150, D2; 300, D3; 450 and D4; 600 ppm) have been applied to irrigation water and their effects on the biomass rate, biomass and grass yield, grass juice yield and $\mathrm{pH}$, plant height and root length, biomass and grass dry matter rate, grass juice energy and macronutrient values (protein, carbohydrate, fat, dietary fiber and ash) were analysed.

\section{Evaluaiton and Measurements}

Biomass rate: It is calculated by proportioning biomass to the seed amount used in the sowing after biomass is weighed on precision scales.

Biomass yield $\left(\mathrm{g} / \mathrm{m}^{2}\right)$ : Biomass yield obtained in $1 \mathrm{~m}^{2}$ is calculated by proportioning total plants harvested after being weighed on precision scales to growing area.

Grass yield $\left(\mathrm{g} / \mathrm{m}^{2}\right)$ : After grass harvested from $1 \mathrm{~cm}$ heigt from root area is weighed on precision scales, grass yield obtained in $1 \mathrm{~m}^{2}$ is calculated by proportioning grass harvested to growing area.

Grass juice yield $\left(\mathrm{g} / \mathrm{m}^{2}\right)$ : Grass harvested is squeezed in grass juicer and grass juice is weighed on precision scales. Grass juice yield obtained in $1 \mathrm{~m}^{2}$ is calculated by proportioning the amounts of grass juice obtained to growing area.

Grass juice $\mathrm{pH}: \mathrm{pH}$ is identified with Lutron $\mathrm{pH}-208$ brand $\mathrm{pH}$ meter in $50 \mathrm{ml}$ sample taken from grass juice.

Plant height $(\mathrm{cm})$ : Plant height is measured over root area with meter in harvest.

Root length $(\mathrm{cm})$ : Root length is measured from grain with meter.

Biomass dry matter rate (\%): After biomass is weighed, $200 \mathrm{~g}$ samples were taken and waited under $70^{\circ} \mathrm{C}$ in an oven until they reach a constant weight and are weighed on precision scales. The obtained values are divided by the biomass weight.

Grass dry matter content (\%): After grass yield is obtained, $50 \mathrm{~g}$ samples were taken and waited under 70 ${ }^{\circ} \mathrm{C}$ in an oven until they reach a constant weight and are weighed on precision scales. The obtained values are divided by the fresh grass weight.

Grass juice energy and macronutrient values: Macronutrient value (protein, carbohydrate, fat, dietary fiber and ash) analyses were conducted by an external laboratory in accordance with AOAC (1990) and their energy values were determined by calculation.

Grass juice mineral contents: Nitrogen was determined in an external laboratory according to AOAC (1990) and $\mathrm{P}, \mathrm{K}, \mathrm{Ca}, \mathrm{Mg}, \mathrm{Fe}, \mathrm{Cu}, \mathrm{Mn}, \mathrm{Zn}$ and $\mathrm{Na}$ in accordance with NMKL-161.

Experimental design and statistical analysis: The completely randomized design was used with three replicates. Data were statistically analysed using analysis of variance (ANOVA) according to the statistical package (JMP, 2007). The "Tukey-Kramer HSD" procedure was used to separate mean values when the F-test was significant $(\mathrm{P} \leq 0.05)$.

Table 1 Some chemical properties of irrigation water

\begin{tabular}{l|clc}
\hline \multicolumn{1}{c|}{ Properties } & $(\mathrm{mg} / \mathrm{l})$ & \multicolumn{1}{c}{ Properties } & $(\mathrm{mg} / \mathrm{l})$ \\
\hline $\mathrm{pH}$ & 6.98 & $\mathrm{Zn}$ & 0.94 \\
$\mathrm{EC}(\mathrm{mS} / \mathrm{cm})$ & 0.59 & $\mathrm{P}$ & 0.20 \\
$\mathrm{Ca}(\mathrm{mg} / \mathrm{l})$ & 116.8 & $\mathrm{~K}$ & 0.03 \\
$\mathrm{Mg}(\mathrm{mg} / \mathrm{l})$ & 10.7 & $\mathrm{Mn}$ & 0.02 \\
$\mathrm{Na}(\mathrm{mg} / \mathrm{l})$ & 2.93 & $\mathrm{Cu}$ & 0.02 \\
\hline
\end{tabular}

Table 2 SeaMax seaweed (Ascophyllum nodosum) extract contents

\begin{tabular}{l|clc}
\hline \multicolumn{1}{c|}{ Contents } & $(\%)$ & Contents (\%) & $(\%)$ \\
\hline Organic matter & 47.5 & $\mathrm{~S}$ & 2.5 \\
$\mathrm{~N}$ & 0.75 & $\mathrm{Fe}$ & 0.004 \\
$\mathrm{P}$ & 0.02 & $\mathrm{~B}$ & 0.006 \\
$\mathrm{~K}$ & 14.9 & $\mathrm{Zn}$ & 0.006 \\
$\mathrm{Ca}$ & 0.3 & $\mathrm{Cu}$ & 0.0002 \\
$\mathrm{Mg}$ & 0.2 & Alginic acid & 5.5 \\
\hline
\end{tabular}




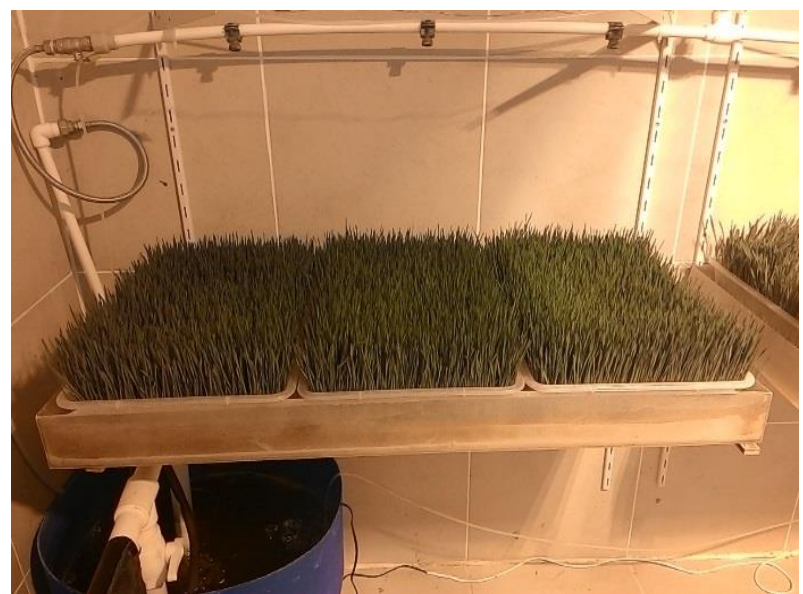

Figure 1 Hydroponic climatization chamber

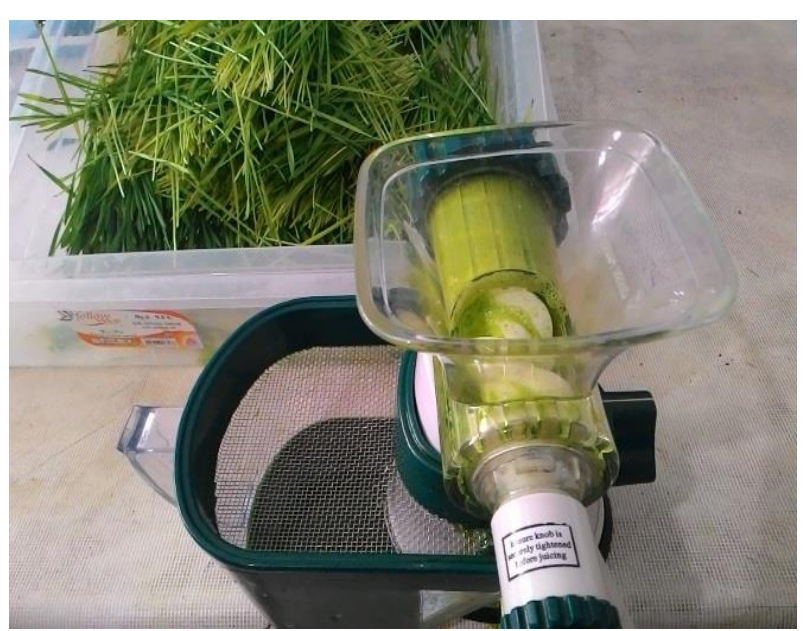

Figure 2 Wheatgrass juicer

\section{Results and Discussion}

Biomass rate, biomass and grass yield: The effects of different doses of seaweed extract applications on biomass rate, biomass and grass yield become statistically significant $(\mathrm{P}<0.01)$. The highest values were obtained from D3 dose application $\left(5.13,20500 \mathrm{~g} / \mathrm{m}^{2}\right.$ and 4167 $\mathrm{g} / \mathrm{m}^{2}$ respectively) but $\mathrm{D} 1, \mathrm{D} 2$ and $\mathrm{D} 4$ dose treatments took part in the same statistical group (a). The lowest values $\left(3.33,13344 \mathrm{~g} / \mathrm{m}^{2}\right.$ and $1600 \mathrm{~g} / \mathrm{m}^{2}$ respectively) were obtained from control treatments and classified in different statictical group (b) (Table 3).

Seaweed extract treatments have led to a significant increase in yield. The findings from the earlier studies related topics also support the research results. Researchers observed that yield increases of seaweed application in tomato (Herrandez-Herrera et al., 2013), in pease (Carvalho et al., 2013), in mango (Mohamed and El-Sehrawy, 2013), in sesame (Pramanick et al., 2014), in lettuce (Trinchera et al., 2014), in wheat (Shahbazi et al., 2015). The availability of macro and micro elements within the seaweed extract, natural growth promoters such as amino acids, vitamins, cytokinin, auxin increase plant growth and yield (Carvalho et al., 2013; HernandezHerrera et al., 2013; Mohamed and El-Sehrawy, 2013;
Zamani et al., 2013; Pramanick et al., 2014; Rajarajan et al., 2014; Shahbazi et al., 2015).

Grass juice yield and $p H$ : The effects of seaweed extract treatments on grass juice yield become statistically significant $(\mathrm{P}<0.01)$. The highest grass juice yield $(3293$ $\mathrm{g} / \mathrm{m}^{2}$ ) was obtained from D3 dose treatment and it took place in different statistical group (a). The lowest grass juice yield $\left(1114 \mathrm{~g} / \mathrm{m}^{2}\right)$ was obtained from control treatment and it took place in different statistical group (c) (Table 3).

Seaweed doses treatments become a significant effect on grass juice $\mathrm{pH}$ values $(\mathrm{P}<0.01)$ and the highest grass juice $\mathrm{pH}$ value (6.17) was obtained from control treatment and it took place in different statistical group (a). The lowest grass juice $\mathrm{pH}$ values (6.0) were obtained from D1, D2 and D4 doses treatments and they took place in the same statistical group (b) (Table 3).

Seaweed extracts from marine algae contain major and minor nutrients and bioactive substances with beneficial effects that enhance root and shoot growth, yield and quality in many agricultural and horticultural crops (Alam et al., 2014). Rajarajan et al. (2014), has stated that seaweed treatments cause to increase in the amount of photosynthetic pigments in plants and Mohamed and ElSehrawy (2013) has claimed that even low doses seaweed treatments can provide high chlorophyll production. It is claimed that this increase in the amount of chlorophyll is caused by the reduction in the degradation of chlorophyll and this is because of betaine found in the seaweed (Sabir et al., 2014; Shahbazi et al., 2015).

Plant height and root length: The effects of different doses of seaweed extract treatments on plant height become statistically significant $(\mathrm{P}<0.01)$, the highest values were obtained from each four (D1, D2, D3, and D4) doses treatments $(15.5 \mathrm{~cm}, 15.7 \mathrm{~cm}, 16.0 \mathrm{~cm}$ and 15.9 $\mathrm{cm}$, respectively) and they all took part in the same statistical group (a). The lowest plant height $(10.8 \mathrm{~cm})$ was obtained from control treatment and it took place in different statistical group (b) (Table 4).

The effects of seaweed extract treatments on root length become statistically significant $(\mathrm{P}<0.01)$. The highest root length $(11.5 \mathrm{~cm})$ was obtained from D3 dose treatment and it took place in different statistical group (a). The lowest root length $(5.8 \mathrm{~cm})$ was obtained from control treatment and it took place in different statistical group (c) (Table 4).

While Rajarajan et al. (2014), have stated that seaweed treatments increase the plant height, Herrera et al. (2013), has reported that zeatin content of the seaweed promote rooting. Matysiak et al. (2011), reported that biologically active alginic acids, polyphenols, free amino acids and natural phytohormones (auxin and cytokine) found in seaweed increase the rooting and growing. Seaweed extracts improve nutrient uptake by roots resulting in root systems with improved water and nutrient efficiency, thereby causing enhanced general plant growth and vigor (Crouch et al., 1990).

Biomass and grass dry matter rates: The effects of different doses of seaweed extract treatments on biomass and grass dry matter rates become statistically significant 
$(\mathrm{P}<0.01, \mathrm{P}<0.05$, respectively), and the highest biomass and grass dry matter rates $(17.1 \%$ and $12.2 \%$, respectively) was obtained from control treatment and it took place in the different statistical group (a). The lowest biomass and grass dry matter rates $(10.5 \%$ and $8.8 \%$, respectively) were obtained from D3 dose treatment and they took place in different statistical group (b) (Table 4). In hydroponic growing, dry matter loss occurs as the result of metabolic activity and respiration with germination. On the 3rd day of germination, chloroplast formation and photosynthesis begin but in this short time (7 days), the dry matter accumulation by photosynthesis cannot meet the loss (Karaşahin, 2014).

Grass juice energy and macronutrient values: Different seaweed dose treatments have not had statistically significant on grass juice energy and macronutrient values (protein, carbohydrate, fat, dietary fiber and ash) (Table 5).

Table 3 Effects of seaweed extract doses on some yield parameters of wheatgrass

\begin{tabular}{|c|c|c|c|c|c|c|}
\hline \multicolumn{2}{|c|}{ Treatments } & $\begin{array}{l}\text { Biomass } \\
\text { rate }\end{array}$ & Biomass Yield & $\frac{\text { Grass Yield }}{\left(\mathrm{g} / \mathrm{m}^{2}\right)}$ & Grass Juice Yield & $\begin{array}{c}\text { Grass Juice } \\
\text { pH }\end{array}$ \\
\hline & Control & $3.33^{\mathrm{b}}$ & $13344^{b}$ & $1600^{b}$ & $1114^{\mathrm{c}}$ & $6.17^{\mathrm{a}}$ \\
\hline Seaweed & D1 & $4.82^{\mathrm{a}}$ & $19267^{\mathrm{a}}$ & $3545^{\mathrm{a}}$ & $2669^{b}$ & $6.00^{\mathrm{b}}$ \\
\hline Extract & D2 & $4.67^{\mathrm{a}}$ & $18656^{\mathrm{a}}$ & $3922^{a}$ & $2944^{\mathrm{ab}}$ & $6.00^{\mathrm{b}}$ \\
\hline \multirow[t]{2}{*}{ Doses (D) } & D3 & $5.13^{\mathrm{a}}$ & $20500^{\mathrm{a}}$ & $4167^{\mathrm{a}}$ & $3293^{\mathrm{a}}$ & $6.07^{\mathrm{ab}}$ \\
\hline & D4 & $5.02^{\mathrm{a}}$ & $20067^{\mathrm{a}}$ & $3958^{\mathrm{a}}$ & $3197^{\mathrm{a}}$ & $6.00^{\mathrm{b}}$ \\
\hline HSD & & $0.44^{* *}$ & $1775^{* *}$ & $463^{* * *}$ & $363^{* *}$ & $0.09^{\text {*** }}$ \\
\hline
\end{tabular}

Table 4 Effects of seaweed extract doses on some parameters of wheatgrass

\begin{tabular}{|c|c|c|c|c|c|}
\hline \multirow{2}{*}{\multicolumn{2}{|c|}{ Treatments }} & Plant Height & Root Length & Biomass Dry Matter & Grass Dry Matter \\
\hline & & \multicolumn{2}{|c|}{$(\mathrm{cm})$} & \multicolumn{2}{|c|}{$(\%)$} \\
\hline & Control & $10.8^{b}$ & $5.8^{\mathrm{c}}$ & $17.1^{\mathrm{a}}$ & $12.2^{\mathrm{a}}$ \\
\hline Seaweed & D1 & $15.5^{\mathrm{a}}$ & $9.3^{\mathrm{b}}$ & $11.8^{\mathrm{b}}$ & $10.6^{\mathrm{ab}}$ \\
\hline Extract & D2 & $15.7^{\mathrm{a}}$ & $9.7^{\mathrm{ab}}$ & $13.0^{\mathrm{b}}$ & $10.5^{\mathrm{ab}}$ \\
\hline \multirow[t]{2}{*}{ Doses (D) } & D3 & $16.0^{\mathrm{a}}$ & $11.5^{\mathrm{a}}$ & $10.2^{\mathrm{b}}$ & $8.8^{\mathrm{b}}$ \\
\hline & D4 & $15.9^{\mathrm{a}}$ & $9.9^{\mathrm{ab}}$ & $10.8^{\mathrm{b}}$ & $11.0^{\mathrm{ab}}$ \\
\hline HSD & & $0.82^{*: 2}$ & $1.35^{* *}$ & $2.71^{* * *}$ & $1.79^{*}$ \\
\hline
\end{tabular}

HSD: Honestly significant difference, ns: not significant, *; $\mathrm{P}<0.05$, **; $\mathrm{P}<0.01$

Table 5 Effects of seaweed extract doses on wheatgrass juice energy and macronutrient contents

\begin{tabular}{|c|c|c|c|c|c|c|c|c|}
\hline \multirow{2}{*}{\multicolumn{2}{|c|}{ Treatments }} & \multirow{2}{*}{$\begin{array}{c}\text { Calorie } \\
\text { (Kcal/Kg) }\end{array}$} & Moisture & Carbohydrate & Protein & Fat & Dietary Fiber & Ash \\
\hline & & & \multicolumn{6}{|c|}{$\%$} \\
\hline & Control & 27.85 & 92.81 & 4.12 & 2.42 & 0.16 & 2.91 & 0.47 \\
\hline Seaweed & D1 & 30.01 & 92.55 & 4.03 & 2.57 & 0.39 & 2.25 & 0.47 \\
\hline Extract & D2 & 30.01 & 92.56 & 4.02 & 2.52 & 0.43 & 1.96 & 0.44 \\
\hline \multirow[t]{2}{*}{ Doses (D) } & D3 & 29.30 & 92.66 & 3.98 & 2.51 & 0.37 & 2.41 & 0.47 \\
\hline & D4 & 26.49 & 93.18 & 3.80 & 2.38 & 0.19 & 2.73 & 0.45 \\
\hline HSD & & $\mathrm{ns}$ & $\mathrm{ns}$ & $\mathrm{ns}$ & ns & $\mathrm{ns}$ & ns & $\mathrm{ns}$ \\
\hline
\end{tabular}

Although no difference is statistically found between energy and macronutrient contents in the analysis on the grass juice, seaweed treatments increase the biomass, grass and grass juice yield and total energy obtained from unit area and macronutrient amounts (Table 4 and 5).

Karaşahin (2015) was conducted a research in order to identify the grass juice yield and nutritional values of some cereals (barley, wheat and corn) grown up in hydroponic environment. In the research, similar macronutrient contents were obtained from wheatgrass juice.

\section{Conclusion}

According to the results, while the highest biomass and grass yield, plant height values were obtained from D1, D2, D3 and D4 treatments, the highest grass juice yield and root length were obtained from D3 treatment. The highest $\mathrm{pH}$ and grass dry matter content were obtained from control treatment. Seaweed dose treatments were not had influence on grass juice energy and macronutrient values (protein, carbohydrate, fat, dietary fiber and ash). However, the rise in the grass juice yield was caused a rise in the total energy and macronutrient values in the unit area. D3 treatment can be recommendable to achieve the highest grass juice yield.

\section{Acknowledgment}

The authors are thankful for the support extended by Karabuk University Scientific Research Projects (BAP). This research consists of a part of the project numbered KBU-BAP-14/1-KA-028. 


\section{References}

Al-Karaki GN, Al-Hashimi M. 2012. Green fodder production and water use efficiency of some forage crops under hydroponic conditions. International Scholarly Research Network Agronomy. 1-5.

Alam MZ, Braun G, Norrie J, Hodges DM. 2014. Ascophyllum extract application can promote plant growth and root yield in carrot associated with increased root-zone soil microbial activity. Can. J. Plant Sci. 94: 337-348.

Anonymous 2012. The medicinal properties and value of wheatgrass Triticum aestivum L. Applied Biological Science (Plant Science). 1-9.

AOAC 1990. Association of Official Analytical Chemists Official Method of Analysis, 15th ed, pp. 66-88. Washington, DC, USA.

Arthur GD, Aremu AO, Moyo M, Stirk WA, Staden JV. 2013. Growth-promoting effects of a seaweed concentrate at various $\mathrm{pH}$ and water hardness conditions. South African Journal of Science. 109 (11-12): 1-6.

Ashok SA. 2011. Phytochemical and pharmacological screening of wheatgrass juice (Triticum aestivum L.). International Journal of Pharmaceutical Sciences Review and Research. 9 (1): 159-165.

Aydos OS, Avcı A, Özkan T, Karadağ A, Gürleyik E, Altınok B, Sunguroğlu A. 2011. Antiproliferative, apoptotic and antioxidant activities of wheatgrass (Triticum aestivum L.) extract on CML (K562) cell line. Turk J Med Sci. 41 (4): $657-$ 663.

Carvalho MEA, Castro PRC, Novembre ADC, Chamma HMCP. 2013. Seaweed extract improves the vigor and provides the rapid emergence of dry bean seeds. American-Eurasian J Agric \& Environ Sci. 13 (8): 1104-1107.

Crouch IJ, Beckett RP, Van Staden J. 1990. Effects of seaweed concentrate on the growth and mineral nutrition of nutrient stressed lettuce. J Appl Phycol. 2: 269-272.

Degraff Loraine R. 2011. The Complete Guide to Growing and Using Wheatgrass: Everything You Need to Know Explained Simply-Including Easy to Make Recipes. Atlantic Publishing Group Inc Florida, USA.

Fazaeli H, Golmohammadi HA, Tabatabayee SN, Asgari-Tabrizi M. 2012. Productivity and nutritive value of barley green fodder yield in hydroponic system. World Applied Sci J. 16 (4): 531539.

Hernandez-Herrera RM, Santacruz-Ruvalcaba F, Ruiz-Lopez MA, Norrie J, Hernandez-Carmona G. 2013. Effect of liquid seaweed extracts on growth of tomato seedlings (Solanum lycopersicum L.). J Appl Phycol. 4: 1-10.

JMP. 2007. Statistic and Graphics Guide, Release 7, SAS Institute Inc, Cary, USA.

Karaşahin M. 2014. Effects of different applications on dry matter and crude protein yields in hydroponic barley grass production as a forage source. Süleyman Demirel Üniversitesi Ziraat Fakültesi Dergisi. 9 (1): 27-33.

Karaşahin M. 2015. Topraksız ortamda yetiştirilen bazı tahılların çim suyu verim ve besin değerleri. Iğdır Üniversitesi Fen Bilimleri Enstitüsü Dergisi. 5(4): 57-64.

Latique S, Chernane H, Mansori M, El Kaoua M. 2013. Seaweed liquid fertilizer effect on physiological and biochemical parameters of bean plant (Phaesolus vulgaris variety paulista) under hydroponic system. European Scientific Journal. 9 (30): 174-191.
Matysiak K, Kaczmarek S, Krawczyk R. 2011. Influence of seaweed extracts and mixture of humic and fulvic acids on germination and growth of Zea mays L. Acta Sci Pol Agricultura 10 (1): 33-45.

Mohamed AY, El- Sehrawy OAM. 2013. Effect of seaweed extract on fruiting of hindy bisinnara mango trees. Journal of American Science. 9 (6): 537-544.

Patel Janki B, Patel Piyush M. 2013. Anticancer and cytotoxic potantial of Triticum aestivum extract on hela cell line. International Research Journal of Pharmacy. 4 (1): 103-105.

Peinado I, Giron J, Koutsidis G, Ames JM. 2014. Chemical composition, antioxidant activity and sensory evaluation of five different species of brown edible seaweeds. Food Research International. 66: 34-44.

Pramanick B, Brahmachari K, Ghosh A. 2014. Efficacy of kappaphycus and gracilaria sap on growth and yield improvement of sesame in new alluvial soil. Journal of Crop and Weed. 10 (1): 77-81.

Rajarajan R, Selvaraju S, Vasanth M. 2014. Effect of foliar spray with seaweed extract on growth and chemical constituents of Crossandra infundibuliformis (L.) nees. International Journal of Advanced Research in Biological Sciences. 1 (8): 29-33.

Rana S, Kamboj JK, Gandhi V. 2011. Living life the natural waywheatgrass and health. Functional Foods in Health and Disease 1(11): 444-456.

Sabır A, Yazar K, Sabır F, Kara Z, Yazıcı MA, Göksu N. 2014. Vine growth, yield, berry quality attributes and leaf nutrient content of grapevines as influenced by seaweed extract (Ascophyllum nodosum) and nanosize fertilizer pulverizations. Scientia Horticulturae. 175: 1-8.

Shah KV, Kapupara PK, Desai TR. 2011. Determination of sodium, potassium, calcium and lithium in a wheatgrass by flame photometry. Pharma Science Monitor An International Journal of Pharmaceutical Sciences. 900-909.

Shahbazi F, Seyyed Nejad M, Salimi A, Gilani A. 2015. Effect of seaweed extracts on the growth and biochemical constituents of wheat. International Journal of Agriculture and Crop Sciences. 8 (3): 283-287.

Sharma SHS, Lyons G, McRoberts C, McCall D, Carmichael E, Andrews F, Swan R, McCormack R, Mellon R. 2012. Biostimulant activity of brown seaweed species from strangford lough: compositional analyses of polysaccharides and bioassay of extracts using mung bean (Vigno mungo L.) and pak choi (Brassica rapa chinensis L.). J Appl Phycol. 24: 1081-1091.

Singh N, Verma P, Pandey BR. 2012. Therapeutic potential of organic Triticum aestivum Linn. (wheatgrass) in prevention and treatment of chronic diseases: an overview. International Journal of Pharmaceutical Sciences and Drug Research. 4 (1): 10-14.

Trinchera A, Marucci A, Renzaglia M, Rea E. 2014. Filtrate seaweed extract as biostimulant in nursery organic horticulture. In: Rahmann G, Aksoy U, editors. Proceedings of the 4th ISOFAR Scientific Conference. Building Organic Bridges at the Organic World Congress, 13-15 October 2014, Istanbul, Turkey. p. 697

Zamani S, Khorasaninejad S, Kashefi B. 2013. The importance role of seaweeds of some characters of plant. International Journal of Agriculture and Crop Sciences. 5 (16): 1789-1793. 